\title{
Propositions for Improvement of Health Care Organization (Lessons of Covid-19 Crisis)
}

\section{Coulic Véry ${ }^{1 *}$, Dobos $S^{1,2}$, Mboti $F^{1,2}$ and Martin $M^{3}$}

${ }^{1}$ Free Brussels University, Laboratory of Translational Research, CHU Brugmann, ICU, Brussels, Belgium

${ }^{2}$ Chu Brugmann, Department of Chirurgie Digestive, Thoracique et Endoscopique, Brussels, Belgium

${ }^{3} \mathrm{CHU}$ Brugmann, Department of Bio-medical Equipmnent, Brussels, Belgium

*Corresponding Author: Coulic Véry, Professor, Free Brussels University, Laboratory of Translational Research, CHU Brugmann, ICU, Brussels, Belgium.
Received: April 25, 2020

Published: June 15, 2020

(C) All rights are reserved by Coulic Véry., et al.

\section{Abstract}

The so called "COVID-19 crisis" has shown some insufficiencies in the national health care services all over the world, the difficulties of WHO to be respected, but also the reserves of local inventiveness and adaptation abilities. The aim of the present work is to try to a better understanding of the possible ways of improving the organization of health care including help to WHO and reinforcing its task.

Keywords: Health Care; Pandemic; COVID-19; Public Hospitals; Health Centres Organization and Funding

\section{Introduction}

Following the development of pandemic Covid-19 disease, the reactions of the different countries governments and those of the international scientific medical society show different tendencies. On the one hand, great national and international movements of cooperation and solidarity were observed [1]. On the other hand incredible difficulties of evaluation and management of the concrete situations leading both to their aggravations and severe augmentation of casualties. Everyone is informed by the Media about the lack of medical devices and material, the lack of places in hospitals and the consequent overload of hospital structures, bad coordination between official and medical organizations and so on [2]. But the crisis has also shown the ability of medical services and employees to act independently from their incompetent ministries and introduce in record time interval the adequate required innovating answers to the problems. For instance - "COVID units", confection of masks and uniforms, were organized as well as the work of medical and paramedical personal in an efficient but humanized way, help of volunteers and so on (see daily instructions for medical and paramedical staff, TV and Web media reports and interviews) .Hospitals were also able to coordinate their activities and help each other at first without central help at first. In China, then in Belgium, France, Italy, Spain, and USA a central coordination was established between health services, army and some industries too (see national papers and journals in March and April 2020).
The analysis of the causes leading, in most of the countries, to such an initial incapacity of the official powers in front of the epidemic situation shows that during the last years prior to 2020 there was a general tendency to "saving up" by contracting the health care budgets [3-16]. In addition, health care was promoted as an enterprise which had to generate profits. For instance, in Belgium, following the passing of AR 15.05.2018 and other ministerial measures [4-8], some "little" first line hospitals were shut, the other ones were invited to reduce personnel, beds, medicine use or to prescribe them only according to a list given by the Ministry of Health Care which simply stopped to refund the other ones. Part of RMI devices, already bought by hospitals, was shut and their use forbidden. As a consequence, radiologists were obliged to work without strict respect of security rules maintaining the units open till late every day. Consequently, the waiting lists became several months long. And this occurred at the very moment when MRI (Magnetic Resonance Imaging) was recommended as safer and had to progressively replace CT scanning even in emergency. Many other measures were launched which had not ever reached neither their economical, nor their medical aim, for instance liquidation of stocks of medical material and devices without their renewal. In France and Great Britain, though health care systems are different, tendency to reduce the State participation to funding and to stir the difference between private and public institution is the same [913]. The situation in USA is still much worse [14-17]. 
Moreover, many private institutions (industrial enterprises, laboratories and other) have tried to take advantage of the situation by increasing their benefits by multiplying their prices by 3 and much more, on the pretext of the supply and demand law. Other institutions have announced their intention to monopolize new treatment means or vaccines again to have the possibilities of rising the prices.

Aim of the present work: taking into account the above-mentioned analysis, to achieve a better understanding of the possible ways of improving the health care organization including help to WHO and reinforcing its task.

\section{Propositions}

Taking into account the main difficulties, encountered in most countries during the pandemic, some propositions were elaborated as a first step. They are not exhaustive and concern three levels of health care: local, national and world organization.

At local level it seems wise to leave to health care institutions (from polyclinics community health centres, dispensaries up to hospitals and clinics) more facilities and autonomy and more responsibility to manage their different problems including budget use according to their own specificities and needs. For instance choosing suppliers, cooperation with other hospitals, opening or closing units, hiring workers, to keep or externalizing services, dressing their drug lists, electing or nominating or periodically changing the services heads, organizing consultations or referendum on some questions. All above mentioned points could only be dependent on the institutions.

In the evaluation of the health institution results it would be necessary to account not only for formal criteria but also for the severity of the admitted patient condition, and also for the social economic situation which influences the disease course, the hospitalization duration and the occupation of the beds, as well as the treatment success or difficulties. Management of the Covid-19 crisis at this first line level has proved that practically all the hospitals and other different medical institutions, including homes for elderly persons, in different countries have adapted to the new situation before the official reaction which generally confirmed and supported the correctness of their decisions and acts.

But this was possible only because, for a short time, the hospitals and clinics were no more considered as enterprises which have not only to respect their budget equilibrium, but also have to be "profitable". This proves that at least public health care institutions must be considered as a State Public Service well-funded by the State Budget without the obligation to generate profits.
The profitability of medicine is neither understandable nor tolerable, as long as young physicians and nurses are invited to pronounce the Hippocrates Oath (Figure 1 [18]).

Councils of specialists and competent experts were created during the crisis that have assisted the Health Authorities in their decisions very efficiently. Is it possible to maintain such flexible a form of "decision making"? As it is the case for the time being, they may include - temporary or not - depending of the submitted problem, the necessary persons (Academicians as well as technicians) who have their former basic remuneration maintained during their work as Advisers. (NB Important that no complementary salary would be paid to prevent these functions being materially attractive for wrong personalities). Without the approval of such a council, the destruction of a medical technique or devices would not be allowed unless the reconversion or repair or relegation or transmission possibility was excluded. This kind of support could increase the convincing influence of the Ministry decrees on the subjects of these decrees more than gathering hundred and hundred opinions of people whose competences were not always proved and surely not evident for the population. It could be a real (and more efficient) help for the Minister than it was up to now.

Another problem which has scandalized every one and cannot be resolved up to now lies in the lobbying. It must be not easy to realize, but lobbying in Health Care domain has to be forbidden. It would not prove so bad for the producers either because of certain money savings, and positively influence their cost prices, even their retail prices... It could give the opportunity of alternative solutions to a medical problem, help new treatments, devices to develop. Example: Robotic surgery (Figure 2) and robots in general can allow access to health care in isolated places or in far from medical help zones. It would be necessary, if not urgent, to overcome the robotic industry present monopole limitations in prevision of future catastrophes.

In correlation with all the above mentioned points, it would be interesting to think about an international convention, according to which all things - drugs, diagnosis or curative chemicals, vaccines, mechanical devices, electronics, robotics and other must be sold at a price no higher 2 or $3 \times$ (for cheap materials) the cost price. This would be controlled by an expert organism and financial police, under UNESCO, WHO and International Court of La Haye.

\section{Discussion}

"Criticism is easy and art is difficult" is a well-known phrase. A longing for improvement of the contemporary health care (and life) conditions can nevertheless be observed all around the world in numerous talks and conversations as well as in papers and articles [19-21]. 


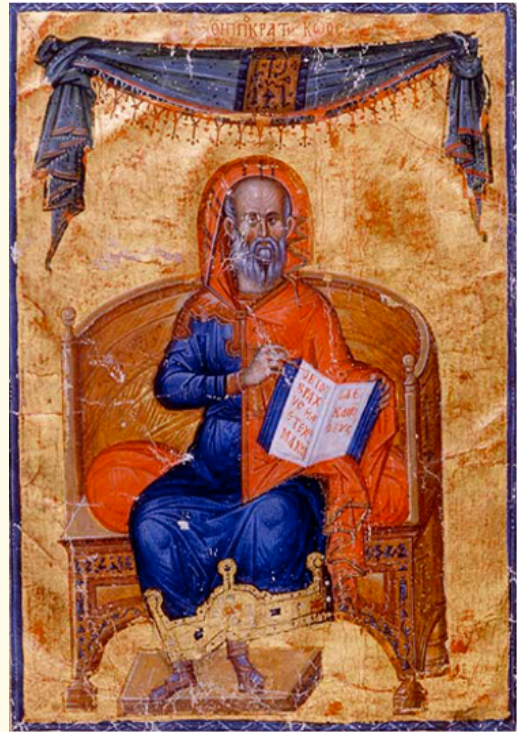

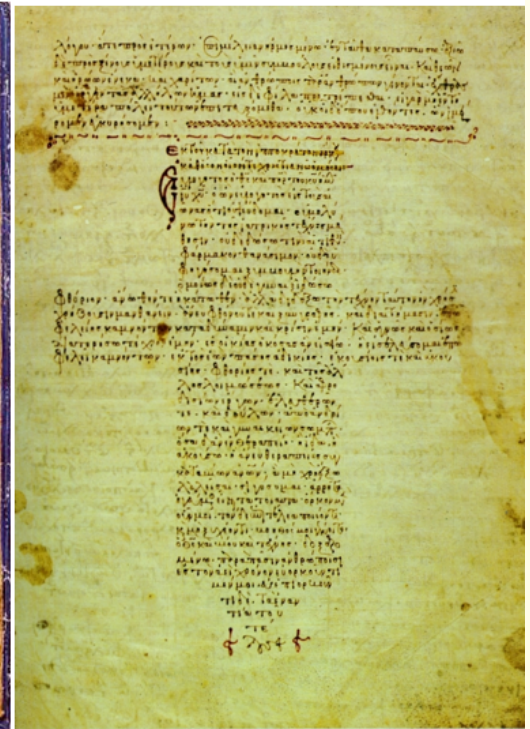

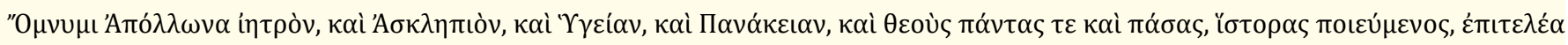

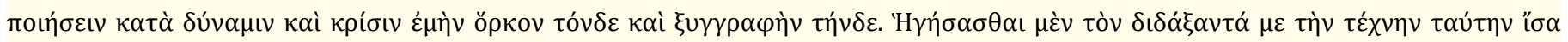

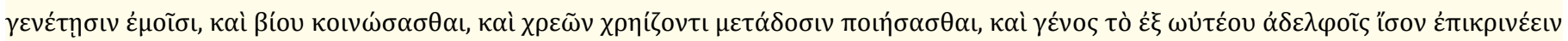

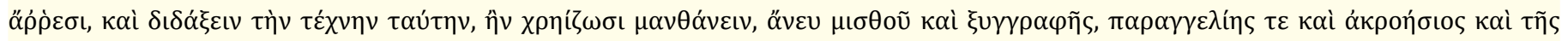

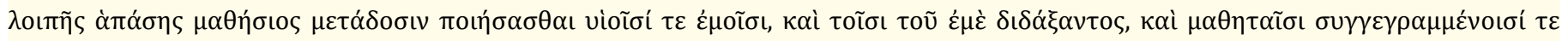

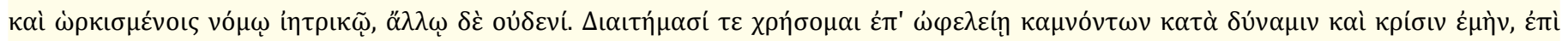

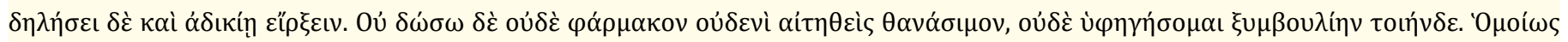

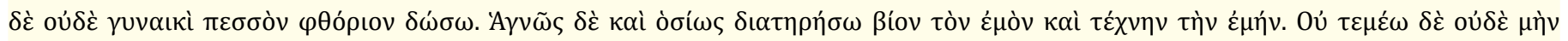

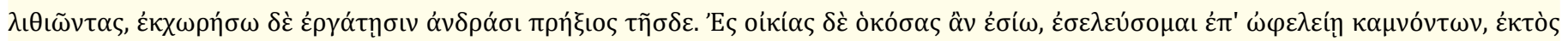

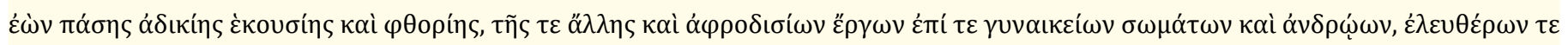

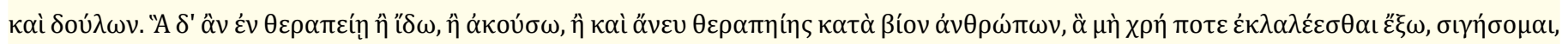

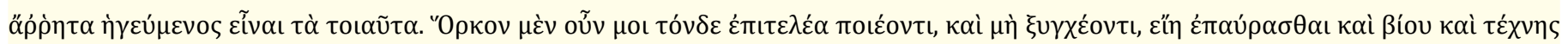

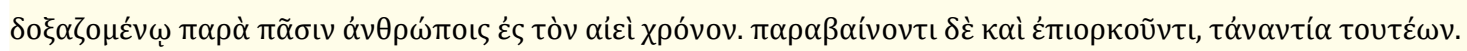

Hippocrates' Oath (Translated by Amelia Arenas) — for Gary Lefer

I swear before my gods, my ancestors, my teachers, my fellow healers and apprentices, and by all the arts and knowledge I was privileged to learn, that I will stand by these words: I will love those who taught me these arts as I love my parents and I will offer my skills to the young with the same generosity that they were given to me. And I will never ask them for gold, but demand that they stand by this covenant in return.

I also swear that if I earn fame and wealth, I will share it with my masters and my students.

I will soothe the pain of anyone who needs my art, and if I don't know how, I will seek the counsel of my teachers. I will offer those who suffer all my attention, my science and my love. Never will I betray them or risk their wellbeing to satisfy my vanity.

I will not hurt my fellow or put a knife to his flesh if I don't know how, or give him an herb to soothe his pain, even if he begs for it in anguish, if it might take away his breath. I will never harm my suffering friend, because life is sacred, from the tender fruit that he once was in his mother's womb to that first sigh he gave out between her legs when he opened his eyes to the world.

I will try to understand his sorrows but his secrets will never leave my ears. Under no circumstance I will use his body to advance my knowledge or my fame, unless in his last moment, he or his widow give me his corpse, so that his death may help me understand how to soothe another's pain.

I pray that the attention I give to those who put themselves in my hands be rewarded with happiness.

And in honor of the knowledge I've received from my teachers, I swear to care for anyone who suffers, prince or slave. If I ever break this oath, let my gods take away my knowledge of this art and my own health.

Here speaks a citizen, a servant of people. May I be destroyed if I betray these words.

C. ОРКОГ

Figure 1: Hippocrates' Oath: A. Representation of Hippocrates (Kos 460 - Larissa 375-335? AC) B. Original text and its Byzantine picture, XXII century, C. English translation of the Hippocrates oath (Translated by Amelia Arenas)-for Gary Lefer, arion 17.3 winter 2010. 

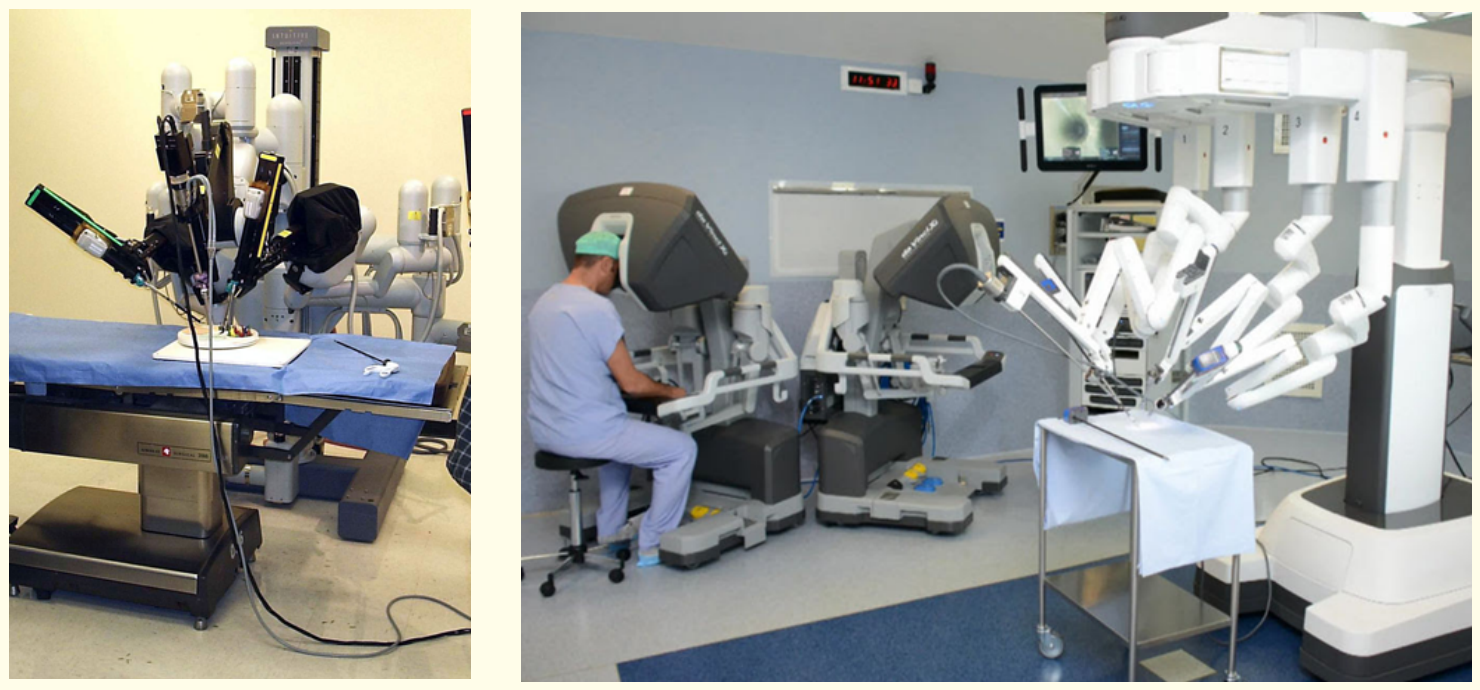

Figure 2: Robot in Medicine as a possible powerful tool to manage patients in epidemic situations.

A. General view (reproduced from Da Vinci web site), B. Surgeon at test work.

Most of the expressed opinions agree with our propositions or implicitly support them. We aimed at being constructive, but, none the less, not to be exclusive and do hope to have been useful.

\section{Conclusion}

1. Covid-19 crisis has pointed not only deficiencies of our Health Care systems, but also ways for their improvement.

2. The main condition of the possible improvement success is to consider Health Care as a Public Affair of the Countries, States, governments, coordinated by better than now empowered and well-funded international institution, WHO.

\section{Acknowledgment}

The authors express their gratitude to M. J-L Kempeneers for its precious logistic help.

\section{Bibliography}

1. Gutteres A. "Une crise qui fait appel à la solidarité". Nations Unies. COVID riposte (2020).

2. Normand M and Rozenblum S. "Corona virus: cette crise qui révèle les lacunes du système sa santé des USA”. Le Monde (2020).

3. Saltman R., et al. "Governing Public Health. Reform strategies and the movement toward institutional autonomy". European Observatory (2011): 25.
4. AR 15.05.2018 Loi coordonnée du 19.17.2018 relative au financement groupé des hôpitaux, Moniteur belge, 18.03.2020, Ed.3 16037.

5. M De Block. "Plan d'approche de la réforme du financement des hôpitaux Global Payement Standardisation” (2018).

6. Réorganiser le paysage hospitalier et le financement des hôpitaux (2019).

7. Florence Daury. "Réforme du paysage hospitalier; la loi de la jungle”. La Libre Belgique (2019).

8. Les hôpitaux universitaires inquiets face à la réforme et aux "reseaux" de Maggie De Block. Agence Belga (2018).

9. Etablissements de santé en France. drees.solidarites-santegvtfr (2018).

10. Castel P and Vincent G. "Statut de l'hôpital public". Communiqué de presse. Wikipedia (2019).

11. Hôpital en France. Financement. (2020).

12. Health Care in Great Britain. Google.be.

13. Frayer L. "UK hospitals are overburdened but the British love them" (2018).

14. Hospitals in USA. Wikipedia.org/Hospital in USA (2019). 
15. Gooch RA and Kahn JM. "ICU beds utilization and health care spending". Journal of the American Medical Association 311.6 (2014): 567.

16. Page KR., et al. "Undocumented US immigrants and Covid-19". New England Journal of Medicine 382.21 (2020): e62.

17. Normand M and Rozenblum S. "Corona virus: cette crise qui révèle les lacunes du système sa santé des USA". Le Monde (2020).

18. E Littré. "CFuvres complètes d'Hippocrate". Volume 4, Baillière, Paris (1844): 628-632.

19. Zacharia A. "Le COVID-19, révélateur de toutes les crises". Le Soir, Acualités (2020).

20. Brown J. "How to conquer a pandemic". Time 195.15-16 (2020): 37.

21. Ban Ki-Moon. "How COVID-19 could aid global relations". Time 15-16 (2020): 37.

\section{Assets from publication with us}

- Prompt Acknowledgement after receiving the article

- Thorough Double blinded peer review

- Rapid Publication

- Issue of Publication Certificate

- High visibility of your Published work

Website: www.actascientific.com/

Submit Article: www.actascientific.com/submission.php

Email us: editor@actascientific.com

Contact us: +919182824667 